
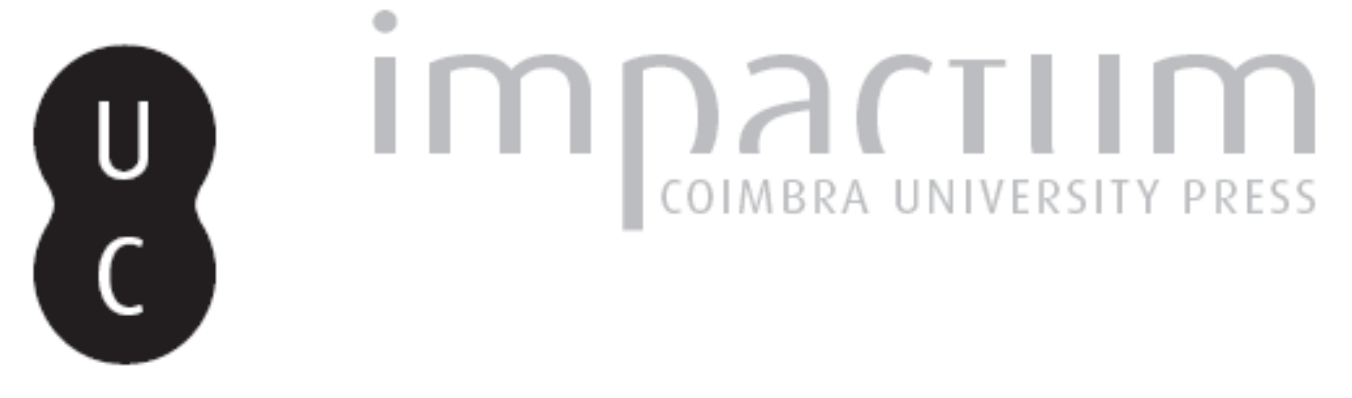

\title{
António Arnaut e a seiva amorosa de cada verso
}

Autor(es): $\quad$ Leão, Delfim F.
Publicado por: Associação Portuguesa de Estudos Clássicos; Instituto de Estudos Clássicos

URL persistente:

URI:http://hdl.handle.net/10316.2/30442

DOI:

DOI:http://dx.doi.org/10.14195/0872-2110_50_10

Accessed : $\quad$ 26-Apr-2023 15:24:28

A navegação consulta e descarregamento dos títulos inseridos nas Bibliotecas Digitais UC Digitalis, UC Pombalina e UC Impactum, pressupõem a aceitação plena e sem reservas dos Termos e Condições de Uso destas Bibliotecas Digitais, disponíveis em https://digitalis.uc.pt/pt-pt/termos.

Conforme exposto nos referidos Termos e Condições de Uso, o descarregamento de títulos de acesso restrito requer uma licença válida de autorização devendo o utilizador aceder ao(s) documento(s) a partir de um endereço de IP da instituição detentora da supramencionada licença.

Ao utilizador é apenas permitido o descarregamento para uso pessoal, pelo que o emprego do(s) título(s) descarregado(s) para outro fim, designadamente comercial, carece de autorização do respetivo autor ou editor da obra.

Na medida em que todas as obras da UC Digitalis se encontram protegidas pelo Código do Direito de Autor e Direitos Conexos e demais legislação aplicável, toda a cópia, parcial ou total, deste documento, nos casos em que é legalmente admitida, deverá conter ou fazer-se acompanhar por este aviso.

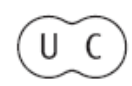




\section{Boletim de \\ Estudos Clássicos}

Associação Portuguesa de Estudos Clássicos Instituto de Estudos Clássicos

\section{Coimbra}

Dezembro de 2008 


\title{
António Arnaut e a Seiva Amorosa de CAda Verso*
}

\author{
Eunomia \\ (Boa Ordem, frg. 4.30-40 West)
}

Que estas coisas ensine aos Atenienses, o meu coração me ordena: que males sem conta à cidade a Desordem traz.

Mas a Boa Ordem bem ordenado e bem disposto tudo faz aparecer e, muitas vezes, nos injustos põe grilhetas.

As asperezas aplaina, põe termo à ambição, a insolência amortece, faz secar as flores da perdição nascidas, endireita a justiça sinuosa, sobranceiras obras rebaixa. Põe termo aos actos de discórdia, põe termo à ira da terrível disputa e, sob a sua influência, tudo, entre os homens, é sensato e prudente.

\section{I}

Estes versos não são de António Arnaut, mas também não foi por acaso que os escolhemos para servirem de abertura à análise da sua poesia. $\mathrm{O}$ autor dos versos citados é Sólon, que os compôs há cerca de dois mil e seiscentos anos, na viragem do séc. VII para o VI a.C., num período particularmente conturbado da história de Atenas. ${ }^{1}$ Além da imagem histórica de grande legislador, está também ligada a esta figura a atitude paradigmática do sábio, que alimentaria a imaginação literária durante séculos, conforme demonstram, em particular, as inúmeras reescritas do encontro (provavelmente inventado) entre Sólon e Creso, o poderoso monarca da

* Este estudo corresponde, no essencial, à comunicação proferida no dia 30 de Outubro de 2008, no âmbito do ciclo de conferências "Comunidade de Leitores", promovido pela Livraria Almedina e, por significativa coincidência, pela filha do autor abordado nesse dia, Ana Paula Arnaut.

1 A tradução dos versos de Sólon é da nossa autoria e provém de um livro anteriormente publicado: Delfim Leão, Sólon. Estadista, poeta e sábio (Coimbra, MinervaCoimbra, 2006). 
Lídia, cuja riqueza e cegueira imensas lhe reservariam um caminho de dolorosa provação. Há, no entanto, um outro aspecto da personalidade de Sólon que contribui de igual forma para fazer do legislador uma das grandes figuras da história da humanidade: o facto de ele ser também o primeiro poeta ático, realidade que é muitas vezes desvalorizada pelos próprios helenistas.

A primeira razão para explicar esse relativo menosprezo parece residir no pressuposto, mais ou menos assumido, de que os versos de Sólon não merecem um lugar de destaque na literatura grega. Pela nossa parte, contudo, cremos que tal subvalorização não só se revela injusta, como talvez a sua verdadeira motivação se encontre na própria importância que o reformador detém na história política e constitucional de Atenas. Por outras palavras, o facto de Sólon ser um destacado estadista parece autorizar uma certa desconsideração implícita da sua obra poética, como se fosse uma qualidade supérflua a alguém que havia alcançado já notoriedade a outro nível.

No entanto, a realidade dos factos remete-nos para um cenário bastante distinto. Nos versos de Sólon, além de um aproveitamento muitas vezes original da tradição literária anterior (em especial da linguagem homérica), ressalta sobretudo a vivacidade das metáforas com que descreve e visualiza a realidade sua contemporânea. Não hesita, inclusive, em salientar o progresso intelectual e a ponderação trazidos pela idade, numa atitude nova e desafiadora, quando confrontada com a lógica do carpe diem, que domina o pessimismo latente na poesia grega arcaica em geral. Não se pode esquecer, igualmente, as reflexões sobre o funcionamento do mundo, sobre a relação entre a natureza humana e a vontade divina, numa das composições mais justamente famosas da literatura grega ("Elegia às Musas"). No entanto, o que o seu universo poético regista de forma especial e mais paradigmática é a expressão apaixonada de uma ética ao serviço da pólis e da comunidade, como nos mostra, de forma sublime, em poemas como "Eunomia" (Boa Ordem) e "Obra do legislador", os dois poemas evocados precisamente para abrir e encerrar este breve estudo.

Ora António Arnaut, além de ser político, orador e poeta, ${ }^{2}$ partilha igualmente com Sólon um tipo de expressão literária profundamente marcada

2 Entre outras figuras que se destacam nesta galeria de políticos e escritores, temos, por exemplo, o estadista senegalês Léopold Sédar Senghor, conhecido como poeta da Negritude e falecido em finais de 2001, ou então Manuel Alegre, cuja 
pelo empenho nas causas da comunidade, fazendo do seu autor um «animal político» na verdadeira acepção que a expressão assume em Aristóteles (Política, 1253a), quando sustenta que «por natureza (physis) o homem é um animal político (politikon zoon)». Ou dizendo de outra forma, o ser humano realiza-se em toda a plenitude através da identificação com a vida numa comunidade, com as suas leis, prioridades e preocupações sociais.

\section{II}

Com efeito, a poesia de António Arnaut é marcada por um profundo sentimento de confiança na capacidade psicagógica da arte poética, ou seja na sua aptidão para ser 'condutora de almas', função essa que se traduz, não raras vezes, num atento empenho social, que reforça o papel do poeta enquanto intérprete e guia do seu tempo, e ainda enquanto agente activo de progresso.

Esta preocupação percorre toda a poesia de António Arnaut e surge mesmo em momentos de relativa distensão criativa, como se pode ver no poema Praia (85), em que a plácida bonomia é interrompida pelo incómodo sentimento da relativa injustiça humana: ${ }^{3}$
Estou aqui sentado à beira da manhã
olhando tranquilamente esta orla de praia onde Agosto descansa como todos os anos neste tempo de mãos cruzadas sobre o ócio. Sinto-me livre, alodial, mas de repente penso que esta manhã não é igual para todos apesar de todos serem iguais perante a lei, não sei por que me zarpou este pensamento intranquilo a questão é que todas as leis mesmo as naturais têm excepções que são como a tal ovelha tresmalhada do rebanho bíblico, ou dito mais claramente, é preciso que uns trabalhem para outros descansarem, é por isso que nem todos têm direito ao ócio, a mais antiga das virtudes humanas,

produção poética sublinha, com frequência, o mesmo empenho cívico do político e parlamentar.

3 Todas as citações são feitas a partir de António Arnaut, Recolha poética (1954-2004) (Coimbra, Coimbra Editora, 2004). 
este homem, por exemplo, de pele curtida pelo sol que nunca gozou férias nem conhece o sentido da palavra afadiga-se a limpar o lixo derramado (...)

A descontracção do poeta encontra-se bem acentuada pelo uso de um termo preciso que reforça a ideia de liberdade total, na medida em que «alodial» é uma palavra da esfera jurídica que se aplica, em especial, à propriedade imóvel, para significar que se encontra livre de vínculos ou obrigações. O poeta estaria, por isso, em condições de desfrutar do «ócio», que não se traduz simplesmente em inactividade, mas antes no vagar e tranquilidade necessários às ocupações do espírito, na senda do otium cum dignitate da tradição clássica. ${ }^{4} \mathrm{~A}$ consciência de que nem todos podem gozar de idênticas regalias, «apesar de todos serem iguais perante a lei», numa alusão implícita a um dos princípios basilares da democracia (a isonomia), transforma-se cada vez mais num «pensamento intranquilo» que se sobrepõe à placidez do momento e leva a considerar que todas as leis têm excepções, «mesmo as naturais». Com esta nota discreta e segundo uma estratégia discursiva recorrente em António Arnaut, o leitor é novamente transportado para os primórdios da democracia e para a discussão, de raiz sofística, sobre o peso relativo da lei natural (physis) e da lei positiva (nomos), criada pela comunidade. Contudo, o poeta não está empenhado em explorar as contradições do binómio, mas antes em afirmar o que possuem em comum: a excepção, neste caso a incapacidade para garantir a todos o mesmo direito ao ócio. Este «pensamento intranquilo», que começara por ser uma reflexão volátil e efémera, vai ganhando cada vez mais espaço na composição, a ponto de tomar conta dela, como denota claramente o facto de a focalização do poema se deslocar do sujeito enunciador para a pessoa inicialmente abjecta do homem que apanha o lixo.

Este empenho cívico que impede o poeta de ficar indiferente à realidade que o rodeia leva-o também, noutras composições, a exprimir o cansaço de viver num mundo postiço, onde, e de forma paradoxal, apenas os cães vadios mantêm uma sombra de liberdade, conforme sustenta na parte final do poema Exaustão do tempo (93-94):

(...)

já não há espaço para uma pessoa reflectir

comprar um livro colher uma flor ou simplesmente

${ }^{4}$ A bem conhecida expressão foi usada por Cícero, De Oratore, 1.1. 
travar o passo nos umbrais da cegueira colectiva

e fazer um aceno amigável ao último cão vadio

que guarda intocada a sua liberdade

de ser cão vadio nesta noite excessiva

de neons cansados pela saturação dos gazes

de ruídos velozes como relâmpagos de sangue (...)

$\mathrm{Na}$ abertura do estudo, referia-se o facto de António Arnaut, tal como Sólon, poder ser considerado um 'animal político' no sentido aristotélico então evocado. Fora essa, aliás, a forma de resolver o dilema explorado pelos Sofistas (e recordado também a propósito do poema anterior), sobre a oposição entre physis e nomos: com efeito, a existência numa pólis, com as suas leis e convenções sociais, constituía o enquadramento natural e necessário para a natureza humana e, por conseguinte, para Aristóteles não havia oposição entre os dois princípios. A esta visão, as novas tendências filosóficas que acompanharam a passagem para a Época Helenística - em especial os Cínicos, com a sua intrínseca rebeldia contra todas as formas de disciplina e convenção social - vinham contrapor que physis e nomos poderiam efectivamente identificar-se entre si, mas somente quando o homem pudesse seguir as inclinações naturais, entendendo o mundo inteiro como a sua cidade, ou seja, afirmando-se como um kosmopolites ou 'cidadão do mundo'. 5 Ora não deixa de ser curioso relembrar que o termo 'cínico' (xuvıxós) significa, à letra, o que 'leva uma existência de cão', na sequência da vida desprendida de Diógenes, a quem atribuíam precisamente a alcunha de 'cão' (xúwv). E é precisamente essa imagem que o poeta, de forma deliberada ou não, traz para o poema, ao «fazer um aceno amigável ao último cão vadio», contrapondo assim a um mundo cego e excessivo a singela figura do animal «que guarda intocada a sua liberdade».

\section{III}

A relação com o Tempo (fundamental de resto também na poesia de Sólon, como se verá no poema que encerra esta análise) é outra das linhas de força da poesia de António Arnaut, sendo no entanto necessário distinguir nele uma tipologia tripartida do Tempo, com implicações bastante distintas.

5 Cf. Diógenes Laércio (6.63), a propósito do cínico Diógenes. Se a resposta for autêntica, permitiria atribuir ao desconcertante filósofo a criação do termo kosmopolites. 
De facto, há o Tempo primordial, da infância, permeado pela ilusão e pela expectativa, regra geral conotado positivamente; há depois a memória colectiva ou Tempo pretérito comum, que o leva a respeitar e honrar o passado da pátria, embora não de forma acrítica; por último, há o Tempo presente, em relação ao qual o autor cultiva, com frequência, uma relação de distanciamento censor e desencanto, precisamente por ser um Tempo exausto, parado e sem futuro, pese embora o impulso natural de procurar intervir nele e de motivar o progresso e a mudança (que podem, ainda assim, traduzir-se numa proposta de regresso a um passado impoluto). Procuraremos ilustrar esta tipologia com a consideração de alguns passos concretos.

Tempo primordial: o poema Árvore tutelar (162) é um dos muitos exemplos onde se evocam as reminiscências da infância, um tempo marcado pela esperança e ilusão enquanto crença pura e despida de preconceitos, um espaço de memória com frequência desacreditado pela experiência do presente, mas que serve de lugar de reencontro do poeta consigo mesmo e com o momento em que começava a descobrir o mundo. António Arnaut chama-lhe «tempo aventuroso da raiz», pois correspondia a uma fase de 'aventuras' de criança e também ao início da 'aventura' de viver, mas igualmente a um período de 'ventura', isto é de felicidade real e espontânea (brotando por isso mesmo da 'raiz'):

A ti me acolho

árvore tutelar da minha infância.

Conheço-te do tempo dos ninhos

quando descobri o mundo

na copa dos teus segredos

e senti no meu tronco

a seiva transbordante do teu corpo.

Por isso volto sempre ao teu regaço

para ver a lua, as estrelas, os pássaros

que pousam nos teus ramos

como os meus olhos em busca

do tempo aventuroso da raiz. 
Na série de poemas sobre o Natal (secção VIII - O pássaro azul), a relação dialógica com o tempo é uma constante, precisamente por influência das memórias puras de infância que o momento especial da quadra natalícia desperta em alguém que sente que, enquanto adulto maculado pela experiência da vida, perdeu já a Fé ou a esperança. Ao longo desses poemas ocorrem expressões positivas como «tempo primordial» (Fogueira apagada, 308), conjugadas com o desejo de «voltar a criança» (Oração II, 313). Ainda assim, tais sentimentos vêem-se por vezes ensombrados pela consciência de quem vive num «Tempo consumado», talvez porque definitivamente pretérito e irrecuperável (Natal profano, 318), ou pela referência melancólica à noite de Natal, idêntica «às outras que o Tempo vai deixando», se bem que a alegria do neto venha lembrar ao poeta que essa noite era mesmo especial (Poema breve, 320), ou ainda pela relação tensa entre Tempo e Templo (no poema Se Cristo voltasse, 324).

Tempo pretérito comum ou memória colectiva: esta temática domina sobretudo a secção VI - Pátria, memória antiga e encontra uma das expressões mais paradigmáticas na composição Os meus heróis (193). Apesar de relembrar várias das figuras que considera modelares na história de Portugal, o autor evoca agora os seus verdadeiros heróis, que não são os símbolos da «nostalgia portuguesa» (que também preza e respeita), mas antes os «heróis dos dias úteis da semana», fazendo assim a ligação a um dos temas igualmente recorrentes na sua poesia, ou seja, ao apreço pela gente simples e anónima que luta pela vida e de quem depende, na realidade, o bom sucesso do país: 6

Prezo os símbolos, o rasto e os sinais

da minha nostalgia portuguesa. Mas

os meus heróis verdadeiros não vêm da história,

não têm monumentos nas praças domingueiras

nem dias feriados a lembrar-lhes o nome,

são heróis dos dias úteis da semana

6 Na mesma secção, há vários poemas que evocam os símbolos oficiais da grandeza do passado português, facilmente reconhecíveis por todos (e.g. Afonso I, As armas, Os títulos, A honra, 200-203), e outros que espelham uma dignidade mais espontânea e discreta (e.g. As ermidas, 199; A saudade, 208). Em Dia de Portugal (236), o poeta reage, no entanto, contra as condecorações «por atacado», como se Portugal fora um «País de heróis e de santos / à beira mar enterrado». 
levantam-se antes do sol e recolhem apenas quando a noite se fecha nos seus olhos, (...)

Tempo presente: cabe agora evocar os momentos em que o autor aborda um Tempo exausto, parado e sem futuro, que com frequência resiste às investidas da poeta para transformar a realidade social. Esse sentimento surge, por exemplo, numa composição com um claro referente epocal, como 25 de Abril (Onze anos depois) (233), mas detecta-se de forma intensa no poema Meu país (231), onde se dá voz à defraudação cada vez maior de alguém que se empenhou pessoalmente no desígnio de alcançar uma nova ordem e a quem cabe também, embora a contragosto, reconhecer que o sonho continua adiado: ${ }^{7}$

Meu país de verão azul

o mar já não sossega

o sonho que em ti navega.

Meu país de outono triste a ferver de mosto e de luar com a alma em riste de se afogar.

Meu país de inverno branco, casas de neve ao sul montanhas de cal ao norte e os rios a chorar a sua sorte.

Meu país de Abril em flor,

7 No poema Sombras (115), afirma-se que «sombras velhas são novos pensamentos / sombras novas são velhas emoções.» Esta intersecção constante de tempo pretérito e presente, de memórias e de acções, de esperanças e desilusões, encontra expressão desenvolvida no romance Rio de sombras (Coimbra, Coimbra Editora, 2007), a obra em prosa mais recente do autor, onde é visível uma notável maturação do processo de escrita, traduzida numa narrativa complexa e envolvente. Notar, ainda assim, a recorrência, no próprio título, de termos que colhem certa predilecção nas opções discursivas de António Arnaut enquanto poeta. 
cheira a cravos, cheira a rosas,

orgia de amor

não consumado.

Meu país adiado.

E a primavera

ainda à espera.

O paralelismo entre as estações do ano, cuja natural beleza não consegue transpor a opacidade da apreensão, encontra o seu ponto mais alto na constatação de que a primavera de Abril continua por se cumprir e de que, portanto, o desejo imenso de uma «orgia de amor» promissora e fecunda permanece, afinal, «não consumado».

\section{IV}

Mas como atrás se comentava a propósito dos protagonistas das penas quotidianas, evocados na composição Os meus heróis, a poesia de António Arnaut exprime também, e a cada momento, a adesão voluntária ao atractivo exercido por desígnios cívicos menos ambiciosos mas igualmente nobres, onde a sensualidade instintiva, o amor singelo e puro, a simpatia (no duplo sentido de 'afeição' e 'partilha de sofrimento') pelo carácter genuíno da existência do povo humilde ou a dedicação à terra ocupam um lugar de eleição.

Será oportuno evocar alguns dos momentos em que essas referências são mais claras. É o que acontece com o poema Lavadeiras do Mondego (95), onde se encontra um dos muitos exemplos de apreço pela gente simples, condenada a uma mesma ocupação, que funciona como refúgio e também como repositório de genuína identidade. Mas ainda assim, as lavadeiras vêem-se ultrapassadas pelas «máquinas da modernidade», das quais nenhum proveito conseguem tirar:

Como choupos debruçados na corrente do tempo e das lendárias águas

do Mondego,

lavam a roupa e as mágoas

ao sol nascente

do seu desassossego.

Corre-lhes no peito a nostalgia 
das águas passadas, a cantar

uma antiga melopeia.

Por isso continuam a lavar,

dia após dia,

o seu destino oculto em roupa alheia.

As máquinas da modernidade

vão tornando inútil o sacrifício

das velhas lavadeiras,

mas elas não sabem outro ofício,

máquinas humanas sem idade

que nunca se cansam das canseiras.

E aqueles - como o poeta - que procuraram vencer o destino marcado e singrar num mundo postiço, na vã expectativa de alterá-lo, acabaram por sofrer dupla penalização, ao sentirem o sabor da derrota e ao compreenderem a situação de 'desterrados' em que ficaram, no sentido de 'exilados do seu ambiente natural', mas também na leitura mais concreta de 'arrancados à própria terra nutriz'. É o que se pode ver, por exemplo, na breve composição Castigo (112):

O castigo das flores é serem postas numa jarra.

As pessoas gostam das coisas artificiais

não sabem que as flores são o rosto da paisagem

o perfume dos dias cansados,

arrancam-nas como quem sacode a sombra

das poeiras de sol.

Que mal fiz eu para me cortarem a raiz

e me desterrarem

da minha condição de camponês?

Este imaginário ligado à ruralidade e à terra encontra-se disseminado por toda a obra poética de António Arnaut, sendo, aliás, um dos traços que mais o aproximam da poesia de Miguel Torga, que constitui muito provavelmente a sua referência literária preferida, a par de outras como a poesia trovadoresca, Camões, Fernando Pessoa (ortónimo e Álvaro de 
Campos), ou ainda a tradição clássica, evocada já ao longo deste estudo. ${ }^{8}$ Por conseguinte, valerá a pena recordar uma das composições onde se verifica essa clara evocação de Torga, como acontece no poema Anteu, dominado, como seria de esperar, pela poderosa simbologia ctónica da «terra», enquanto força nutriz, mas também enquanto «chão», ou seja, realidade dura e concreta, onde se podem colher «estrelas verdadeiras» (349):

É da terra que venho e me alimento, na terra sonho, entre mar e céu, a terra me dá asas como ao vento, a terra me dá forças como a Anteu.

A terra é o meu espaço sem fronteiras (e quando digo terra, digo chão) onde recolho estrelas verdadeiras, caminhante arrimado ao seu bordão.

Da terra vim, à terra hei-de voltar quando a noite cobrir o horizonte, como rio moribundo a procurar $o$ alento germinal da sua fonte.

É interessante notar que a imagem do rio é muito frequente em António Arnaut, pela ligação à força vital da água, à mudança e evolução contínuas. Ainda assim, só muito raramente o poeta faz com que o rio desemboque na foz, talvez por isso querer significar que o rio realizaria o seu destino por completo. Ora esta simbologia do rio parece estar ao serviço do que atrás se disse sobre a noção de um Tempo presente, parado e sem futuro, sem alento para cumprir desígnios que vão além de simples interesses imediatos. ${ }^{9} \mathrm{Em}$

${ }^{8}$ Cf. Aparição (155), Interlúdio (156), Cantiga de amigo (223), Camões (224), Fernando Pessoa (225), Miguel Torga (226). A presença do imaginário clássico foi já por nós discutida num trabalho anterior dedicado especificamente a essa temática: “Tradição clássica na poesia de António Arnaut”, Boletim de Estudos Clássicos 29 (1998) 113-124; os resultados dessa abordagem foram em parte republicados em “António Arnaut e a tradição clássica”, Artes \& Artes 16 (1999) 6-7.

9 A expressão «rio do Tempo», que ocorre no poema Sempre (Poema melancólico de amor) (365), possui, no entanto, outro sentido, remetendo antes para a 
vez da foz, António Arnaut prefere quase sempre o regresso à pureza das origens, ao «alento germinal da sua fonte», conforme sustenta na composição acima reproduzida. De resto, não deixará de ser significativo que o poema Miguel Torga (226) constitua um dos poucos exemplos onde António Arnaut acolhe o imaginário da 'foz do rio', talvez por estar a prestar homenagem a um outro poeta que muito admira e que terá cumprido efectivamente a sua missão:

Poeta total e celular,

fiel como um rio à sua foz:

poeta é o profeta que dá voz

à esperança do futuro que há-de chegar.»

\section{$\mathbf{V}$}

Antes de encerrarmos esta análise, não se pode também deixar de referir que, na poesia de António Arnaut, se vislumbra sempre, em pano de fundo, a eterna sedução de quem encontra na poesia uma forma ideal de criação artística. O papel fecundante do logos, ordenador do caos estéril, aparece muitas vezes combinado com o telurismo orgânico e estrutural do autor, em momentos em que refere o «sopro da emoção» ou «as flores e os frutos da palavra feita arado», conforme sustenta no poema em prosa Metáfora (87). Os efeitos positivos do alento criador da palavra poética emergem de novo em Legado (83), uma composição que assume também contornos de testamento poético: ${ }^{10}$

inscrição da «luz vagarosa de cada instante» de amor numa tentativa ilusória de apreensão «do rosto fugaz da eternidade».

${ }^{10} \mathrm{Na}$ abertura da secção III - Identificação, há um longo poema sem título (ou eventualmente uma série de pequenos poemas unidos pelo assunto, 101-107) que acentua a missão social e estética do poeta, bem como as origens humildes de alguém cujos «antepassados eram cavadores». Em O poema impossível (118), coloca-se novamente a questão do legado literário, que o poeta não se sente capaz de forjar, terminando embora com uma revelação oracular: «É de esperança a mensagem que me grita, / indecifrável no silêncio da raiz.» Em Musa incrédula (121), um poema com discretas ressonâncias clássicas, o leitor é convidado a partilhar o dilema da inspiração arredia. Em Musa antiga (122), António Arnaut convoca novamente o imaginário clássico, articulando-o com outra simbologia recorrente nos seus poemas, contribuindo assim para engrossar um mesmo e indistinto caudal poético: «Voltas, musa antiga, persistente, / a agitar-me o altar das emoções / que foram a seiva dos 
Um dia, a esta mesma hora, quando os pássaros despertam a manhã, num banco de jardim, à mesa de um café, entre um esgar de tédio e um sorriso de esperança, enquanto o comboio não chega e a ânsia do encontro se prolonga como trepadeira sobre a névoa,

ou quem sabe, na penumbra duma cela onde o tempo é um lugar desabitado, alguém lerá estes poemas passando apressadamente os olhos sobre a rama verde das palavras, ou penetrando até ao húmus onde corre a seiva amorosa de cada verso, e aí colherá a mensagem oculta como quem desfolha uma flor silvestre num campo orvalhado de melancolia, (...)

A referência à «seiva amorosa de cada verso», além de remeter o leitor para a intensidade que o sentimento amoroso e a mundividência feminina detêm na poesia de António Arnaut, reforça igualmente o empenho apaixonado e pessoal do criador no processo de dar vida à sua criatura artística. Apesar disso, a afirmação também pode ser entendida como um tributo aos artistas que o antecederam. ${ }^{11}$ Já vimos que Camões, Fernando Pessoa e Miguel Torga ocupam um lugar de eleição enquanto referências literárias do autor. Mas também a antiguidade clássica é um imaginário muito recorrente, bem como a linguagem iniciática de matriz maçónica (especialmente nos poemas retirados da secção VII - Nobre arquitectura). ${ }^{12}$

meus versos / como no tempo em que os rios / transbordavam, límpidos, no mastro da esperança.»

11 De resto, a expressão «seiva dos meus versos» aparecia também na composição Musa antiga, evocada na nota anterior.

12 A este respeito, o poema Acácia (270) é paradigmático, pela forma hábil e segura como o autor conjuga toda uma série de símbolos maçónicos que serão retomados noutras composições da mesma secção. Nesse poema, apresenta-se como sibilina a afirmação «O mistério é o segredo que se sente / mas não se pode exprimir», 
Já no passado analisámos a presença das religiões mistéricas gregas nos poemas do autor, ${ }^{13}$ mas há que reconhecer que a linguagem maçónica constitui talvez uma influência mais directa, se bem que ambas as tradições contribuam para a afirmação do carácter profético da palavra poética, primordial, e apareçam inclusive fundidas numa só corrente de pensamento. ${ }^{14}$

Não iremos, porém, abordar esta vertente da poesia de António Arnaut, sendo que a evocamos agora somente como convite à leitura. Em vez disso, propomo-nos encerrar o estudo tal como o iniciámos, valendo-nos de um recurso tipicamente clássico - a composição em anel - , que consiste em retomar no termo de uma composição o motivo de abertura. Dado que o mote para a abordagem foi dado pela evocação de Sólon, será também com um poema da sua autoria que iremos encerrar esta análise. Trata-se da composição a que demos o título de "A obra do legislador", também neste aspecto quadrando com uma das facetas de António Arnaut enquanto homem de Estado, e que ilustra bem as dificuldades por que passa quem se empenha numa causa política e social. E se os concidadãos nem sempre estão dispostos a reconhecer os méritos dessa acção, possa ao menos a justiça do Tempo cumprir esse desígnio, tomando por testemunha a Terra negra, libertada pela acção do poeta/legislador (frg. 36 West):

porquanto verbaliza, de facto, a essência das correntes mistéricas. De assinalar, ainda, em Nobre arquitectura (273), os versos «e descobre a esquadria onde a essência / do mito se transforma em ritual»; esta aliança entre mito e ritual constitui, de facto, outra característica comum às religiões iniciáticas.

13 Vide supra n. 8.

14 O poema em prosa Aurora triunfante (298) é curioso precisamente por acentuar a maneira como o imaginário maçónico do Mestre Hirão (morto por três maus companheiros que queriam roubar-lhe o santo-e-senha da Criação, há já três mil anos), se cruza com o mito clássico do fio de Ariadne. De resto, a precedência do «mármore ático burilado» vem expressa em Árvore (300). Em Intérmino Caminho (301), o autor refere, entre os ascendentes da maçonaria, Ceres, Elêusis e Pitágoras, ou seja, os mistérios de Elêusis e o Orfismo/Pitagorismo. 


\section{Obra do legislador}

Mas eu, dos objectivos com que reuni

o povo, algum há que deixei por atingir?

Pode testemunhá-lo na justiça do tempo

a mãe suprema dos deuses olímpicos,

a melhor, a Terra negra, de quem eu, outrora,

os marcos arranquei, por todo o lado enterrados:

dantes era escrava, agora é livre.

Muitos a Atenas, pátria fundada pelos deuses, reconduzi, vendidos ora injustamente

ora com justiça. Uns, ao jugo

das dívidas fugiam - e já nem a língua ática

falavam, por tanto andarem errantes;

outros, na própria casa servidão vergonhosa

sofriam, trémulos aos caprichos dos senhores;

eu os tornei livres. Isto atingi com o poder, a um tempo força e justiça harmonizando,

e cumpri quanto havia prometido.

Leis, tanto para o vilão como para o nobre, que para cada um recta justiça ajustavam, escrevi. Mas se outro, que não eu, o aguilhão tomasse, alguém que fosse malvado e ambicioso, não haveria contido o povo; pois, se eu desejasse

o que aos meus opositores então agradava e ainda o que, contra eles, outros meditavam, de muitos homens ficaria viúva esta cidade. Por isso, ao acudir em socorro a todo o lado, qual lobo, acossado pela matilha, me revirei.

DELFIM F. LEÃO 